\title{
ENVIRONMENTAL PROBLEMS AND POLICY RESPONSE IN HONG KONG: AN EVALUATION FROM AN INTERNATIONAL LEGAL PERSPECTIVE
}

\author{
Roda Mushkat*
}

\section{APPLICABILITY OF INTERNATIONAL ENVIRONMENTAL LAW TO HONG KONG}

Before discussing Hong Kong's compliance with international environmental law, it may be desirable to examine whether, and to what extent, the relevant provisions pertain to the Territory. As observed by an international expert in the field, ${ }^{1}$ the law of the environment is a new form of international law, similar in many respects to human rights law, in that it has developed beyond the mode of reciprocal obligations between individual States to broader concepts of duties erga omnes to protect the environment for the benefit of the international community as a whole and, indeed, for the entire human race, including future generations.

Some commentators, in fact, locate the normative basis of international environmental law within the context of human rights, as the entitlement to a healthy environment is increasingly viewed as a fundamental human right. ${ }^{2}$ First enunciated at an international level in 1972 by the UN Conference on the Environment, the right of persons to "freedom, equality and adequate conditions of life, in an environment of a quality that permits a life of dignity and self-being ${ }^{n},{ }^{3}$ has since been reaffirmed in governmental ${ }^{4}$ and non-governmental ${ }^{5}$ meetings as well as incorporated in the constitutions of numerous States. ${ }^{6}$ Indeed, such a right is in full

\footnotetext{
* Reader in Law, University of Hong Kong.

1. See A. KISS, Droit International de l'Environnement (Paris: Editions A. Pedone, 1989).

2. See generally W. P. GORMLEY, Human Rights and Environment. The Need for International Cooperation (Leyden: A.W. Sijthoff, 1976).

3. 1972 Stockholm Declaration on the Human Environment. UN Doc. A/CONF. 48/14 (1972), 11 ILM (1972) 1416 [ hereafter: Stockholm Declaration].

113

Ko Swan Sik et al. (eds.), Asian Yearbook of International Law, Volume 2, 113-126

(c) 1994 Kluwer Academic Publishers. Printed in the Netherlands
} 


\author{
accord with the guidelines laid down by the UN in respect of emerging \\ human rights. ${ }^{7}$
}

It is in any event clear, that in addition to a large body of treaty law, ${ }^{8}$ some norms embodying an international duty of care in relation to the environment have assumed the status of customary international law binding on all nations. Thus, as aptly reflected in their practice (coupled with the relevant opinio juris), ${ }^{9}$ States have accepted responsibility based on the principle of sic utere tuo ut alienum non laedas, namely of not using

4. See, e.g., 1989 Hague Charter Declaration on the Environment, 28 ILM (1989) 1308 (proclaiming the "right to live in dignity in a viable global environment").

5. See, e.g., Draft Charter on Environmental Rights and Obligations, adopted at the UN Experts Meeting in Oslo, Norway, 29-31 October 1990, 21 Environmental Policy and Law (1991) 81 ("Everyone has the right to an environment adequate for his general health and well-being").

6. E.g., Spain, Portugal, Peru, Yugoslavia, Poland. A duty imposed on the government to protect the environment is included in the constitutions of Greece, Switzerland, the People's Republic of China [PRC], USSR, Sri Lanka. See MARKS, 'Emerging Human Rights, a New Generation for the 1980's?', 33 Rutgers Law Review (1981) 435, 443.

7. It is consistent with the existing body of human rights law; it is of fundamental character and derives from the inherent dignity and worth of the human person; it gives rise to identifiable and practicable rights and obligations; there exists generally an implementation machinery; it attracts broad international support. See G.A. Res. 41/120, UN GAOR 41st sess. Supp. No. $53(\mathrm{~A} / 41 / 53)$ at $178(1987)$.

8. For a useful collection of relevant treaties, see A.C. KISS (ed.), Selected Multilateral Treaties in the Field of the Environment (Nairobi: UNEP, 1983). There is no universal treaty imposing clear obligations on States to protect the environment or to prevent its pollution. There are, however, many treaties which touch on these issues in connection with the primary purposes of these treaties, e.g., the 1958 Geneva Convention on the High Seas (Arts. 24, 25); 1967 Outer Space Treaty (places an obligation on states parties to conduct the exploration of outer space so as to avoid harmful contamination or adverse changes in the environment of the earth resulting from the introduction of extra-terrestrial matters - Art. IX; 1979 Moon Agreement (parties assume duty not to alter the natural balance of the environment by introducing adverse changes or by contamination with extraneous substances, or by any other means Art. 7); 1968 Non-Proliferation Treaty (imposes a ban on nuclear tests in the atmosphere Art. 1): 1982 Convention on the Law of the Sea (Part XII, Arts. 192-237). In addition, there is a fairly large body of multilateral conventions which regulate specific aspects of environmental protection, e.g., 1954/1971 International Convention for the Prevention of Pollution of the Sea by Oil; 1971 Convention on International Liability for Damage Caused by Space Objects; 1972 Convention for the Prevention of Marine Pollution by Dumping from Ships and Aircrafts; 1974 Convention for the Prevention of Marine Pollution from Land-Based Sources and its 1986 amending Protocol; 1976 Convention on Civil Liability for Oil Pollution Damage Resulting from Exploration for and Exploitation of Seabed Mineral Resources; 1979 Convention on Long-Range Transboundary Air Pollution and its 1984/1985 Protocols; and most recently, 1985 Vienna Convention for the Protection of the Ozone Layer and 1987 Montreal Protocol on Substances that Deplete the Ozone Layer. The conventional body of rules is further buttressed by regional agreements, e.g., the 1970 Nordic Convention on Protection of the Environment; 1976 Barcelona Convention for the Protection of the Mediterranean Sea against Pollution, and Protocols; 1978 Kuwait Regional Convention for Cooperation on the Protection of Marine Environmental Pollution; 1981 Abidjan Convention for Cooperation on the Protection and Development of the Marine and Coastal Environment of the West and Central African Region, and Protocols; 1983 Catagena de Indias Convention for the Protection and Development of Marine Environment of the Wider Caribbean Region; 1986 Convention for the Protection of the Natural Resources and the Environment of the South Pacific Region, and Protocols concerning Cooperation in Combating Pollution Emergencies in the South Pacific Region and for the Prevention of Pollution of the South Pacific Region by Dumping. Finally, many treaties in this field are of a bilateral nature governing environmental issues in border areas or regulating shared natural resources (e.g., US/Canada; US/Mexico). 
their territory in a manner contrary to the rights of others. Such a primary obligation has been further elaborated ${ }^{10}$ as consisting of a series of four duties - to prevent environmental harm, provide timely notice and information to affected parties, conclude environmental cooperation agreements to minimize expected damage, and repair loss when injury occurred.

While as yet not codified nor forming part of an integrated Asia-Pacific strategy, certain norms may also be said to emerge in the form of "softer law", giving expression to the environmental needs and priorities of the region. Regarded as authoritative in this context are the recommendations and guidelines formulated by ESCAP-organized experts' meetings ${ }^{11}$ and intergovernmental conferences. ${ }^{12}$

As a "subject" of international law in possession of an international legal personality, ${ }^{13}$ Hong Kong has international obligations incumbent upon it and may be held internationally liable for their breach. In particular, given Hong Kong's control, jurisdiction and regulatory capacity ${ }^{14}$ over its people ${ }^{15}$ and territory, the Government's responsibility for the management, use, development, lease or grant of land and natural resources, ${ }^{16}$ and its power to render decisions affecting the environment

9. See references cited in R. MUSHKAT, 'The Daya Bay Nuclear Plant Project in the Light of International Environmental Law', 7 UCLA Pacific Basin Law Journal (1990) 87, 88-9, notes 7-10.

10. See, in particular, the Schematic Outline presented in R. QUENTIN-BAXTER, Special Rapporteur, Fourth Report on International Liability for Injurious Consequences arising out of Acts not Prohibited by International Law, (UN Doc. A/CN.4/373 and Corr. 1 \& 2), reproduced in Yearbook of the International Law Commission, 1983 Vol. 2 Part 1 at 223.

11. See, e.g., Recommendations of the Expert Group Meeting, Tokyo, 5-11 June 1984, in Integration of Environment into Development: Institutional and Legislative Aspects (Bangkok: ESCAP, 1985). For a summary of the recommendations, see R. MUSHKAT, 'International Environmental Law in the Asia-Pacific Region: Recent Developments', 20 California Western International Law Journal (1989-90) 21, 28, note 36.

12. See Recommendations of Intergovernmental Meeting, Bangkok, 26-30 November 1984 and Report of the Ministerial-Level Conference on Environment and Development in Asia and the Pacific, Bangkok, 15-16 October 1990, IHE/MCED/Rep. 19 November 1990.

13. See R. MUSHKAT,'Hong Kong as an International Legal Person', 8 Emory International Law Review (1992) 105.

14. Contemporary discussions of international responsibility, especially in the area of international environmental law, emphasize jurisdiction competence (i.e., competence to make and apply law) and effective control over territory as the bases for ascription of international responsibility. See Fourth Report, supra n. 10 at paras 7-8 (analogy is drawn with the duties owed by a State as the territorial controlling authority in respect of aliens within its borders); see also Julio BARBOZA, Special Rapporteur, Fourth Report on International Liability of Injurious Consequences arising out of Acts not Prohibited by International Law, UN Doc. A/CN.4/43, and related discussion by the International Law Commission in its 2075th meeting on 7 July 1988, in Yearbook of the International Law Commission 1988 Vol. 1 at 222. Indeed, the various ILC's reports reflect recognition of the need for a new system of international obligations in which the source of international liability is the mere causal connection between an activity and occurrence of serious harm rather than a wrongful act on the part of, or imputed to, the governing authorities.

15. Including vessels or aircraft possessing the "Hong Kong nationality". 
based on its political, economic and social objectives, the local authorities incur the corollary international duties regarding protection of the environment and prevention of environmental harm to others.

Thus, Hong Kong's responsibility may be engaged as a result of violations of international environmental norms that are binding on the Territory either under applicable treaties or as part of customary international law which is incorporated in the local law. ${ }^{17}$ Additionally, in view of the pivotal role played by Hong Kong in the region's economic affairs, the Government is also expected to abide by the norms which have been accepted as regional environmental law. ${ }^{18}$

\section{ENVIRONMENTAL PROTECTION IN HONG KONG}

Notwithstanding derogatory references to Hong Kong's "record" in environmental protection, ${ }^{19}$ there is little doubt that environmental issues loom larger on the current political agenda of the Territory, and both the Government and the private sector ${ }^{20}$ are more attuned to environmental concerns. A reasonably sound institutional infrastructure has been erected, indeed boosted, ${ }^{21}$ and numerous laws enacted ${ }^{22}$ in an effort to arrest the degradation of the environment and improve the quality of environmental life in the Territory. It should nonetheless be explored to

16. It may be interesting to note that this responsibility is to be maintained post-1997 under the Basic Law of the Hong Kong Special Administrative Region [HKSAR] of April 1990, Art. 7. 17. In accordance with established British judicial practice, customary international law forms part of the common law of England and hence applicable as part of the law of Hong Kong. On the "incorporation doctrine" and its limits of application, see R. MUSHKAT, "International Human Rights Law and Domestic Hong Kong Law, in R. WACKS (ed.), Hong Kong's Bill of Rights Problems and Prospects (Hong Kong: Faculty of Law, University of Hong Kong, 1990) 25.

18. See supra ns. $11 \& 12$ and corresponding text.

19. Hong Kong has been described as a "traditional bastion of environmental insanity". See C. LONSDALE, 'Time to Take Polluters in HK to task', SCMP 29 December 1990 . The Territory has also been said to have "a First World Economy but a Third World Environment". See M. APPLEYARD, 'Time to Tackle Pollution. HK's Third World Environment', SCMP 26 March 1989.

20. Note, e.g., the high-powered Private Sector Committee on the Environment [PSCE] established in 1988 with the aim of addressing critical environmental problems. The PSCE is comprised of the territory's "hongs" such as the Hong Kong Bank, Swire, Jardine, Wharf (Holdings), Hutchison Wampoa and the South China Morning Post.

21. What began as a small environment protection "unit" within the Government in 1980 developed into an "agency" in 1981 and a fully fledged "department" in 1986. At the higher echelons of government administration, the environment has been given added status with the creation on 1 September 1989 of a new Planning, Environment and Lands Branch in the Government Secretariat. Another significant structural change has been the establishment of both the Drainage Services Department and the Planning Department on 1 January 1990.

22. Included major pollution control ordinances such as the Water Pollution Control (1980), Waste Disposal (1980), Air Pollution Control (1983) and Noise Pollution Control (1988). 
what extent Hong Kong has conformed with applicable international environmental norms.

\subsection{Sustainable Development}

Hong Kong's response to what has recently ${ }^{23}$ been asserted to be the most crucial element of the new international environmental order namely, "sustainable development" - is particularly significant, given the Territory's vigorous pursuit of economic growth and development. Proclaimed by the World Commission on Environment and Development in $1986,{ }^{24}$ the principle of sustainable development has since been reaffirmed in numerous resolutions and statements by various international bodies. ${ }^{25}$ It obliges all nations, regardless of the state of development, to integrate environmental considerations into their development policies and programmes with a view to ensuring long-term economic development while preserving and improving the quality of life of present and future generations.

Hong Kong has not incorporated the concept of sustainable development into its constitutional framework or legal system, nor has a national policy embracing such an aim been adopted. ${ }^{26}$ Indeed, a perception that economic growth and the environment are incompatible goals and that

23. See Communiqué issued by the environmental ministers of 24 nations at an OECD meeting held on 31 January 1990, cited in 14 Environmental Reporter (13 February 1991) 87.

24. See WCED, Legal Principles for Environmental Protection and Sustainable Development, 25 ILM (1986) 494, also WCED, Our Common Future (Oxford: Oxford University Press, 1987).

25. The WCED's findings and recommendations were endorsed in General Assembly Resolutions 42/186 and 187, 11 December 1987. See also UNEP, Statement by the Governing Council on Sustainable Development, 19 Environmental Policy and Law 122-2; Declaration by the seven major industrial nations (G7) at the Summit of the Arch in Paris on 16 July 1989, ibid. at 183; Langkawi Declaration on the Environment made at the Commonwealth Heads of Government Meeting in Kuala Lumpur on 18-24 October 1989, 15 Commonwealth Law Bulletin (1989) 1545-47; Communiqué of the OECD Meting of Environmental Ministers on 31 January 1990, supra n. 23. At a regional level, see Resolution XLIV adopted by the Economic and Social Commission for Asia and the Pacific [ESCAP] in its April 1988 session, 6 ESCAP Environmental News (April-June 1988) 5-6; Ministerial Declaration on Environmentally Sound and Sustainable Development in Asia and the Pacific in ESCAP, Report of the Ministerial-Level Conference on Environment and Development in Asia and the Pacific, Bangkok, 15-16 October 1990, IHE/ MCED/Rep. (19 November 1990) Annex II.

26. Compare with other countries in the region, e.g., the national policies and measures on environmental development incorporated in the National Development Plan of Thailand; Japan's National Economic and Social Plan embraces the goal of promoting a general environmental policy within the plan (although Japan does not have a national policy of sustainable development as such); in the Philippines the Environmental Policy Presidential Degree (PD 1511) which recognizes the inalienable right of people to a healthy environment is backed up by an Environment Code (PD 1152); Indonesia has promulgated Act No. 4, 1982 which contains Basic Provisions for the Management of the Living Environment and serves as a constitutional yardstick for judging the validity of all legislation related to aspects of the living environment. See ESCAP, Integration of Environment into Development: Institutional and Legislative Aspects (Bangkok, 1985). 
the former should be accorded priority have characterized many policy debates in Hong Kong and constrained government administrations in tackling the Territory's environmental problems. ${ }^{27}$

Progress towards recognition of the issue is reflected in the Government's White Paper: Pollution in Hong Kong - a Time to Act, released on 5 June 1989. Acknowledging that "the main reason why our environment is now in an unsatisfactory state is that in the past the Government and community made choices which gave too little emphasis to the needs of the environment", the Government has undertaken to "give greater emphasis to the environment in the future ${ }^{n} .{ }^{28}$ To achieve this objective, a new Planning Environment and Land Branch was established "to ensure that due attention is given to environmental aspects and their integration into the planning system". ${ }^{29}$

Yet, the qualifying statement that "the increased emphasis on improving the environment must not ignore the needs of the economy"30 suggests that the Government continues to view economic and environmental concerns as inherently incompatible, and betrays an attitude far removed from the notion of interdependence and mutual reinforcement which underlies the international concept of "environmentally sound and sustainable development".

Similar conceptual ambivalence is evident in the status envisaged for the environment in the policy matrix of Hong Kong's post-1997 Government. Thus Article 119 of the Basic Law of the Hong Kong Special Administrative Region may provide some basis for concern over the territory's future environment, given the fact that the perfunctory statement that the Government "pay regard to the protection of the environment" is loosely appended to an explicit directive to the Government of the SAR to "formulate appropriate policies to promote and coordinate the development of various trades such as manufacturing, commerce, tourism, real estate,

27. See, e.g., Legislative Council's [LegCo] debates that preceded the passing of the Water Pollution Ordinance in 1980 (resulting in a diluted form of the legislation originally proposed as well as in a much delayed declaration of Water Control Zones) and, more recently, the Amendment to the same Ordinance, infra n. 39. It may be interesting to quote a member of the Legislative Council who put forward the "industrial standpoint" as follows: "We support the environmental protection policies. On the other hand, we are obliged to remind the Government that environmental protection policies on the principle of 'killing the hens to get the eggs' would not be in favour of our economic development". Hong Kong Hansard, Reports of the Sittings of the Legislate Council of Hong Kong, Session 1990/91 at 143 (24 October 1990). See also the insignificant place accorded to environment-based considerations in LegCo debates concerning the Government's massive Port and Airport Development Strategy [PADS] announced in October 1989.

28. Para. 1.5 .

29. Para. 1.8 .

30. Para. 1.7. 
transport, public utilities, services, agriculture and fisheries" and features at the end of a detailed chapter entitled: Economy.

It is also evident that in the absence of clear priorities for the allocation of Government resources, implementation of policies and programmes rides on the vagaries of whichever forces are ascendant when budget allocations are made. ${ }^{31}$ Hong Kong, in common with other countries in the Asia Pacific region, has displayed considerable weakness in implementation and enforcement of environmental policies. ${ }^{32}$ While such weakness is rooted largely in inadequate financial, technological and administrative resources, it may also be induced by the low public demand for environmental quality and the limited leverage of concemed interest groups. ${ }^{33}$

\subsection{Pollution Control}

Although no binding international rules are imposed with respect to the pollution control techniques to be adopted by States, prescriptions regarding environmental impact assessments [EIAs] ${ }^{34}$ and OECD recommendations pertaining to the "Polluter-Pay Principle" $[P P P]^{35}$ have been widely accepted as authoritative in the context of environmental manage-

31. While the Government of the day has placed the environment, along with education, public health and security, as priority programmes that will be spared from the worst cuts in a time of austerity, preferences may be reconsidered to accommodate the Port and Airport Strategy on which its reputation is staked. It has been suggested that there are already signs that notwithstanding "political" assertions of commitment, environment does not feature prominently on the "administrative" agenda, as demonstrated, for example, by the Government's decision to grant the Environmental Protection Department only a quarter of the extra 371 staff it has requested to help enforce toughened legislation. See Editorial, 'Keep Priority Status for the Environment”, SCMP 2 March 1991, at 12.

32. Note, e.g., that although Hong Kong is divided into 10 Water Control Zones [WCZs] - in respect of which the Government has declared Water Quality Objectives as specified in the Water Pollution Control Ordinance - enforcement measures have been undertaken so far only in relation to four such zones (leaving the most polluted local body of water, Victoria Harbour, without protection under any environmental legislation). Lack of manpower has been cited by officials as the reason for phased introduction of WCZs, but observers have suggested that sufficient resources are not forthcoming because the Hong Kong Government which "traditionally has close relationship with industry" is "unwilling to force the territory's thousands of polluting factories to comply with the Water Pollution Control simultaneously". See Hong Kong's Environmental Challenge. Moving from Grey to Green (Hong Kong: Business International Asia/Pacific Ltd., 1991) at p. 58.

33. Notwithstanding the proliferation in recent years of environmental pressure groups (e.g., Green Power, Friends of the Earth, the Conservancy Association, Elefriends HK, the Friends of Black River) such organizations have tended to coalesce around single issues on an ad hoc basis and have had a rather modest effect of governmental policies. It may be noted that some acknowledgment of the need to promote public awareness and support for environmental protection is reflected in the Government's White Paper. Observing that "environmental awareness and general appreciation of environmental issues in Hong Kong are still well below that in most developed countries", the Government has stated its overall objective for environmental education and set out plans for expansion of training and awareness programmes. 
ment. The Hong Kong Government, while recognizing the "need for planning activities to give due consideration to environmental factors" ${ }^{n 6}$, has not formally incorporated EIAs as prerequisites in all planning processes. ${ }^{37}$ Instead, informal EIAs procedures are followed which are confined to major private and public sector development projects. ${ }^{38}$ By the same token, the principle that costs of pollution be borne by the polluter is yet to be adopted by the Government. The administration's choice of a "permit system", rather than the recommended PPP or some form of economic sanction, may illustrate the desire, reflected in the various local pollution control measures, not to impose an undue burden on the manufacturing sector. ${ }^{39}$ Nor has the Government opted to follow an increasingly preferred ${ }^{40}$ integrated legislative environmental protection system and continues to rely extensively on "non-legal devices". ${ }^{41}$ As noted

34. See, e.g., ESCAP, Guidelines for Planners and Decision Makers (1985). The Economic Commission for Europe has recently (26 February 1991) adopted a convention requiring all (26) signing nations (including the US, Canada and Eastern European countries) to establish an environmental impact assessment process and allow other nations the right to participate in that process.

35. See Recommendation of the Council of 26 May 1972 on Guiding Principles concerning the International Economic Aspects of Environmental Policies, C(72)128, 14 ILM (1975) 236; Recommendation of the Council of 14 November 1974 on the Implementation of Polluters-Pay Principle, $C(74) 223$, ibid. at 234 . The principle means that the polluter should bear the expense of carrying out measures drawn up by public authorities to ensure that the environment is in an acceptable state. Disincentives commonly take the form of user and pollution taxes.

36. White Paper: Pollution in Hong Kong - a Time to Act, supra text at n. 28, para. 6.14.

37. Assessments are thus not required by law and their findings do not have to be heeded even if they cause severe pollution or other problems.

38. It should be noted, though, that the Government announced recently, in a "radical" policy reversal, that it would publish and make available to the public environmental impact assessments of significant development projects. See J. ALLEN, ' 'Green' Reports to be Made Public', SCMP 18 December 1990, at 2 . Whether the Government would necessarily use such assessments as "blue-prints for action" has nonetheless been questioned. See Editorial "Testing Hong Kong's Environmental Resolve', SCMP 27 May 1991, at 18 (in connection with a report highlighting health hazards of a land reclamation scheme said to be regarded by the Government as a fait accompli project). Proposals are being prepared, however, by the Environmental Protection Department for legislative means to enforce private developers' duty to provide environmental impact assessments. See K. GRIFFIN, Environmental Law to Enforce Reports.', SCMP 4 June 1991, at 2.

39. New Air Pollution Control (Fuel Restriction) Regulations 1990, introducing sulphur emission controls, were nonetheless approved by the Legislative Council despite pressure from the industrial lobby concerned with rising fuel costs. (Yet the Government has decided not to phase out diesel-powered vehicles - notwithstanding health risks posed by the emission of sulphur and particulates from diesel engines - for fear of "fueling" the current high inflation rate. See K. GRIFFIN, 'Inflation Fears Stop Fuel Switch', SCMP 24 June 1991, at 1). Another piece of legislation long resisted by industrialists - the Water Pollution Control (Amendment) Ordinance - has also been brought into operation (on December 1990), imposing stricter controls and new standards on industrial discharges. (The Government did back down, however, in face of industry opposition in requiring toxic metal discharges to be reduced by 94 percent rather than 97 percent as proposed earlier). It is also reported that legislation is being drafted to require factories to pay for some of the polluted water they discharge. See $\mathrm{K}$. GRIFFIN, 'Factories set to Pay for Discharge of Pollutants.', SCMP 18 June 1991, at 3.

40. See, e.g., UK Environmental Protection Act 1990. 
above, ${ }^{42}$ several ordinances and regulations have been enacted which regulate specific sectors and, while generally tightening control, the legislation falls short of establishing a legal "duty of [environmental] care" which would facilitate effective redress for affected persons. ${ }^{43}$

At the same time, Hong Kong has sought to implement its international duties of pollution control by the incorporation of relevant conventions into the domestic law. Most notably, the Government has enacted the Ozone Layer Protection Ordinance 1989 to give effect to obligations under the 1985 Vienna Convention for the Protection of Ozone Layer ${ }^{44}$ and the 1987 Montreal Protocol on Substances that Deplete the Ozone Layer, ${ }^{45}$ to freeze its consumption of chlorofluorocarbons [CFCs] at 1986 levels from 1 July $1990 .{ }^{46}$ Accordingly, the Ordinance controls - through a registration and licensing scheme - the import and export of "scheduled substances" which deplete the ozone layer. It prohibits the manufacture of these substances, and prescribes heavy fines for non-compliance. ${ }^{47}$

International obligations pertaining to marine pollution control have also found local legislative expression. Thus, Hong Kong's Merchant Ship-

41. Such as "codes of practice", "technical memoranda", Governor's Directions and Departmental Practices. A detailed discussion is provided in an unpublished paper by $M$. J. DOWNEY, Non-Legal Devices and the Legislative Control of the Environment (1990). The author concludes, that while the use of non-legal devices allows for a degree of flexibility, it is not consistent with the "Rule of Law" principle.

42. See supra, n. 22.

43. Note, in particular, that under the various pollution control ordinances the Crown is exempted from criminal liability for non-compliance and is further protected from any other proceedings (including civil proceedings or applications for judicial review). An individual may not be able, therefore, to compel the Government to either perform its statutory duties or, alternatively, comply with the relevant statutory prohibitions. It has also been argued that fines stipulated in the relevant statues, as well as court-inflicted penalties, are far too low to deter polluters. Calls have been made, for example, for the imposition of stiffer sentences on repeat offenders. See 'Campaign Sputters as Priorities Change in Hong Kong', 24 Business Asia (17 June 1991) 208.

44. 26 ILM (1987) 1516.

45. Ibid., at 1541.

46. It may be noted that further legislation is contemplated to take account of changes agreed upon at the second meeting of the parties to the Montreal Protocol (see Helsinki Declaration on the Protection of the Ozone Layer, 2 May 1989, 28 ILM (1989) 1335, namely to allow 100 percent of the 1986 levels until 1 January 1995 and then a progressive decrease to zero on and after 1 January 2000 to require the decrease of non-essential halons progressively from 1 July 1995 to zero on and after January 2000. The Hong Kong administration is also assuming that the recommended Adjustments and Amendments to the Montreal Protocol Concerning the Control of Other CFCs and Carbon Tetrachloride (30 ILM (1991) 537) would be adopted (following ratifications by 20 or more parties) and is preparing the necessary legislation. See Hong Kong Hansard 1990, (14 November 1990) pp. 429-30.

47. A licensee who contravenes conditions of his licence is liable to a one million [HK] dollars fine and two years imprisonment. Note that a Tsuen Wan magistrate recently increased a fine to about ten percent of the value of CFCs imported without a licence, following submission by the Environmental Protection Department that the original fine was too small given (a) the seriousness of the ozone layer problem; (b) that penalties had deliberately set up to deter; and (c) Hong Kong's obligations under international accords. Reported in SCMP 10 May 1990. 
ping (Prevention and Control of Pollution) Ordinance 1989 seeks to incorporate two major international conventions that are applicable to the Territory, namely the 1969 International Convention Relating to the Intervention on the High Seas in Cases of Oil Pollution Casualties, ${ }^{48}$ supplemented by the 1973 Protocol to that Convention, ${ }^{49}$ and the 1973 International Convention for the Prevention of Pollution from Ships [MAR$\mathrm{POL}],{ }^{50}$ including additional protocols and annexes. ${ }^{51}$ Two other international conventions pertaining to oil pollution - the 1969 International Convention on Civil Liability for Oil Pollution Damage ${ }^{52}$ and the 1971 International Convention on the Establishment of an International Fund for Compensation for Oil Pollution Damage ${ }^{53}$ - have also been sought to be implemented locally by means of Hong Kong legislation, ${ }^{54}$ the Merchant Shipping (Liability and Compensation for Oil Pollution) Ordinance 1990. The Territory's international obligations with respect to the curbing of ocean dumping of toxic wastes are discharged (pending "localisation $^{\text {n55 }}$ ) under the Dumping Sea Act (Overseas Territories) Order 1975 which gives effect to the 1972 Convention on the Prevention of Marine Pollution by Dumping of Wastes and Other Matters ${ }^{56}$ and the 1978 Amendments to Annexes I and II of the Convention which have been extended to Hong Kong.

\subsection{Conservation of Nature}

The Territory's input into the world's conservation strategy ${ }^{57}$ has been through enforcement of its international obligations under the 1973 Convention on International Trade in Endangered Species of Wild Flora and Fauna (CITES) ${ }^{58}$ Consistent with such obligations, the Government has prohibited import and export of rhino horn-powder, extending con-

48. 9 ILM (1969) 25.

49. 68 AJIL (1973) 577.

50. 12 ILM (1973) 1319.

51. lbid., at 1439 et seq.

52. 8 ILM (1969) 453.

53. 11 ILM (1972) 284.

54. Previously, the conventions had been in force in Hong Kong by virtue of UK Orders in Council.

55. Since British Acts applicable to Hong Kong would fall away as the Hong Kong Special Administrative Region comes into being on 1 July 1997, relevant laws need to be passed by the local legislature in order to survive the transition to Chinese sovereignty.

56. 11 ILM (1972) 262.

57. In 1980 the International Union for the Conservation of Nature and Natural Resources (IUCN) with the World Wildlife Fund International (WWFI) and the United Nations Environmental Programme (UNEP) published proposals for international action under the title "World Conservation Strategy". See 6 Environmental Policy and Law (1980) 77, 102. 
trols - under the Animals and Plants (Protection of Endangered Species) Amendment 1989 - to any substance containing rhinoceros ingredients.

More controversial has been Hong Kong's commitment to ban all trade in raw ivory in accordance with the upgrading by CITES of the African elephant to fully protected species (under Appendix 1$).{ }^{59}$ Described as a "major blow to the industry" in the Territory which has the world's largest stockpile of ivory ${ }^{60}$ the move naturally triggered fierce protests from local traders. ${ }^{61}$ In fact, economic expediency has triumphed, at least temporarily, over conservation considerations as the United Kingdom agreed to enter a reservation for Hong Kong to be exempted from the world-wide ban on ivory trading for six months (until 18 July 1990). Doubts have been cast besides on the ability of the authorities (more specifically the Agriculture and Fisheries Department) to enforce the ban, given "the Department's poor record on conservation and pollution issues" ${ }^{n} .62$

Conservationists have also criticized the inadequate implementation of another international convention applicable to Hong Kong, namely the 1971 Ramsar Convention on Wetlands of International Importance Especially as Waterfowl Habitat. ${ }^{63}$ The Government is yet to designate a wetland in the Territory for inclusion in a list of Wetlands of International Importance, as required under the Convention, although the Mai Po marshes would be ideally suited. ${ }^{64}$

\subsection{Nuclear Safety}

Although Hong Kong itself does not operate a nuclear power plant, the construction of such a plant by the People's Republic of China [PRC] in Daya Bay, about fifty kilometres from Hong Kong's urban area, makes it an indirect party in a scheme involving international obligations. Arguably, given the magnitude of the environmental risk posed, the Hong Kong Gov-

58. 12 ILM (1973) 1088. The Convention provides for total trade bans in species threatened with extinction (as listed in Appendix D) and the strict regulation of species (listed in Appendix II) which, although not necessarily threatened now with extinction, may become so unless regulated.

59. See Report in 19 Environmental Policy and Law (1989) 215.

60. J. ALLEN, 'CITES Bans Sale of Old lvory Stocks', SCMP 18 October 1989, at 3.

61. See E. FITZPATRICK and J. S. WONG, 'Ivory Traders to Seek Compensation', SCMP 19 October 1989, at 7; E. FITZPATRICK, 'Threat to Retaliate over Ivory Protests', SCMP 1 November 1989 , at 7 .

62. See Editorial, 'Money Talks in Ivory Trade Ban Climbdown', SCMP 20 January 1990, at 18. 63. 11 lLM (1972) 963.

64. The "China/1997 factor" has been invoked to explain the Government's inaction; the PRC is not a party to the Convention. 
ernment should not assume a passive position, but implement appropriate preventive measures. Such measures, moreover, need not be viewed as infringement of Chinese sovereignty or interference in the PRC's internal affairs for they would be grounded in rights arising from "impact territoriality ${ }^{n}{ }^{65}$ Indeed, relevant initiatives by Hong Kong would be consistent with the contemporary trend of vesting States with greater powers to control external sources of environmental hazards. ${ }^{66}$

At the same time, Hong Kong as the "exposed State" is entitled to insist on a cross-boundary environmental cooperation agreement which would enable the local authorities to ensure that the plant operators are maintaining appropriate safety standards, to monitor radioactivity at close range, to exchange information and to coordinate contingency planning for the Territory. Such an agreement should require the PRC to share technical information with Hong Kong, to cooperate in implementing any quality standards stipulated in the treaty, to notify Hong Kong of known potential environmental hazards, to combine technical resources, to abate any existing pollution-generating nuisance, to coordinate relevant national policies, and to prepare transnational environmental impact statements. Lastly, the agreement should require the Chinese Government to continue consulting with the local Government for the purpose of suppressing environmental risk and to prepare contingency plans which may be acted upon if an environmental harm within the ambit of the treaty occurs. In addition to establishing obligations and standards of conduct, the agreement should set up administrative machinery (e.g. a joint commission) for the enforcement of the rules and standards prescribed by the instrument. Finally, a comprehensive agreement could also indicate the remedies available to victims of transboundary harm emanating from the Daya Bay nuclear plant. To guarantee that these remedies will be effective, the agreement should establish a compensation fund for

65. For a discussion of the concept of "impact territoriality", see M.S. MCDOUGAL and J. SCHNEIDER, 'The Protection of the Environment and World Public Order: some Recent Developments', 45 Mississippi Law Journal (1974) 1085, 1112.

66. As evidenced, e.g., by the oil pollution damage conventions, such as the 1969 Convention Relating to Intervention on the High Seas in Cases of Oil Pollution Casualties, supra n. 48, which authorizes parties to take such measures as may be necessary "to prevent, mitigate or eliminate grave and imminent danger to their coastline or related interests from pollution or threat of pollution of the sea by oil, following upon a maritime casualty or acts related to such a casualty, which may reasonably be expected to result in major harmful consequences"; and the 1969 Bonn Agreement concerning Pollution of the North Sea by Oil, 9 ILM (1970) 539. See also the 1982 Convention on the Law of the Sea, 21 ILM (1982) 1261. States have also assumed extraterritorial powers to protect their environmental integrity by municipal legislation. See, e.g., the American Water Quality Improvement Act, Pub. L. 91-224, sec. 11, 84 Stat. 91 (1970); Australian Navigation Act 1912-1973, 8 Austl. Acts P; Australian Protection of the Sea (Powers of Intervention) Act 1981; Canadian Arctic Waters Pollution Prevention Act, Can. Rev. Stat. Ch., A-12 (1985) (by which Canada claimed jurisdiction over an extensive area of the sea for anti-pollution measures) and the Oil in Navigable Waters Act, Ch. 21 (1971). 
victim relief or a compulsory third-party insurance scheme on the riskcreator side.

\subsection{Duty to Cooperate}

In general, to conform with the duty to cooperate in good faith in matters concerning the protection and improvement of the environment, ${ }^{67}$ the Hong Kong Government should seek to forge bilateral pacts with the PRC. ${ }^{68}$ Cooperation may be particularly applicable with respect to the maintenance of transboundary natural resources, such as the Pearl River Delta, and the prevention and abatement of transboundary environmental interference, such as in the Daya Bay nuclear plant context. Recent experience may also suggest that, notwithstanding Hong Kong's most charitable reaction to China's environmental calamities, ${ }^{69}$ both parties may benefit from a joint effort to explore in a pro-active fashion ${ }^{70}$ possible means of abatement.

\section{CONCLUDING OBSERVATIONS}

Hong Kong's remarkable economic progress and the relative prominence which it enjoys in international affairs arguably impose on the Territory considerable responsibilities in the environmental domain. An affluent and outward-looking community cannot remain oblivious to normative developments which reflect universal concerns about the growing imbalance between resource utilization and environmental preservation.

Hong Kong has responded to the challenge inherent in reconciling these two imperatives by constructing a fairly elaborate legislative and institutional framework in an attempt to minimize damage to the environment. Given the low-level of grass-root's environmental activism, and the

67. See the Stockholm Declaration, supra n.3.

68. Some informal cooperative arrangements are already in place, e.g., the Hong Kong-Guandong Environmental Protection Liaison Group. The group has recently received for consideration a report by its technical sub-group identifying certain key areas for future cooperation, including the preservation of the Mai Po marshes [supra n. 64], fisheries, human health, navigation \& development and land use. See K. GRIFFIN, 'Pollution Group Identifies Five Problem Areas', SCMP 3 June 1991, at 5.

69. China's disastrous flooding has been attributed, inter alia, to climate changes brought about by continuing accumulation of greenhouse gases. See C. TAM, 'Floods Triggered by a Mystery Phenomenon', The HK Standard, 19 July 1991, at 8 (citing TU QIPU, Vice-President of the Nanjing Institute of Meteorology who identifies four contributing factors: greenhouse effect, sunspots, volcanic eruptions and El Nino Phenomenon).

70. Whether through the creation of research and information centres, monitoring, transfer of technology or funding. 
cultural predisposition towards utilitarian values, the Territory's achievements in this sphere are by no means negligible.

Be it as it may, local performance falls in some respects short of international expectations. Environmental and natural resource management still ranks low on the Government's priority list, ${ }^{71}$ implementation is slow, ${ }^{72}$ the approach to the problem is characterized by preoccupation with short-term economic and political crises, and is biased towards remedial - as distinct from preventive - measures. In the absence of determined action to place environmental decision-making on a firmer footing, promote environmental causes at the community level (through, inter alia, non-governmental organizations), and forge closer links with other countries/international agencies in the region, the quality of environmental life in Hong Kong will continue to lag behind that enjoyed by people in the developed part of the world.

71. The share of public expenditure allocated by the Government for environmental protection and improvement in 1991-1995 is as follows: $90 / 91-1.8 \% ; 91 / 92-3.1 \% ; 92 / 93-3.5 \% ; 93 /$ 94 - 2.9\%; 94/95 - 2.5\%. See Sir PIERS JACOBS, 1991-1992 Budget Speech (March 1991), Appendix B. Note, however, that in real terms, the percentage change (comparing 1990/91 and 1994/95) in spending on environmental programmes is $61 \%$, ibid., at 24 .

72. See Campaign Sputters as Priorities Change in Hong Kong, supra, n. 43, for a list of major projects lagging behind their original target (including building of a chemical treatment plant, legislation to control handling of asbestos and noise on construction sites, plans to amend air pollution laws to increase penalties). 